\title{
MUHAMMADIYAH MEMPERKUAT MODERASI ISLAM MEMUTUS RADIKALISME
}

\section{Zuly Qodir}

\begin{abstract}
Abstrak
Tulisan ini menjelaskan bahwa Muhammadiyah sebagai organisasi sosial keagamaan, tetap berijtihad untuk menyemaikan gagasan Moderasi Islam di Indonesia. Ijtihad ini memiliki konsekuensi logis Muhammadiyah tidak akan berada pada posisi liberal atau ultra liberal maupun fasisme kiri yang juga ada komunisme di sana. Muhammadiyah mendorong moderasi dalam berislam karena Indonesia memiliki kultur Islam yang tidak sama dengan Islam di Timur Tengah. Islam Indonesia lebih berkarakteristik washatiyah-tengahan, tidak ke kanan atau pun ke kiri. Dalam memperjuangkan gagasan Islam Moderat ini, Muhammadiyah mengembangkan pelbagai aktivitas yang dikenal sebagai amal usaha dalam bidang pendidikan, rumah sakit, panti asuhan dan belakangan pemberdayaan kaum mustadhafin. Gagasan ini, sekalipun tidakserta merta mengatakan Kami Indonesia, Kami Pancasila dan NKRI Harga Mati, buat Muhammadiyah keindonesiaan harus terus dijaga dan tidak boleh dirobohkan oleh kelompok manapun sebab negara ini merupakan negara kesepakatan banyak elemen bangsa yang telah bersusah payah merebutnya dari kolonialisme-penjajahan.
\end{abstract}

Kata kunci: Muhammadiyah, Moderasi, Keindonesiaan, non Radikalisme 
Gagasan tentang Moderasi Islam penting menjadi perhatian sebab dalam sepuluh tahun terakhir arah keislaman dan keindonesiaan tampak oleng oleh gerakan-gerakan ekstrem. Baik ekstrem keagamaan maupun ekstrem ekonomi dan politik. Resurgency Islamisme menjadi penanda dalam demokrasi liberal. Islamisme Islam bergerak dari beberapa sisi dan wilayah yang ada di Indonesia, seperti kampus dan jamaah pengajian. (Arifianto, 2019). Oleh sebab itu, perlu menjadi perhatian banyak pihak sehingga Islam Indonesia tidak mendapatkan kesan sebagai agama yang bersifat oposan terhadap negara karena menyebarkan intoleransi bahkan kekerasan fisik. Sekalipun moderasi Islam mendapatkan kritik sebagai bagian dari kampanye negara atas gerakan islamisme dan terorisme yang bermula tahun 2001 di Amerika pasca runtuhnya gedung kembar Pentagon USA. (Steger, 2004).

Radikalisme agama memang terjadi dalam kehidupan, sebagaimana radikalisme lainnya di belahan bumi manapun. Stigma radikalisme Islam itu begitu kuat dan kadang bersentuhan dengan Islamophobia, yang akarnya kompleks, sebagaimana dijelaskan Esposito dan Deyra (2018): "radicalism is used interchangeably when referring to Islamist radicalism or generically to denote levels of extremity. Islamophobia and Islamist Radicalism are exclusivist ideologies which survive and thrive by blaming, defaming and despising the other and such exclusivist ideologies do not occur in a vacuum". Fakta sosial pun tidak terbantahkan adanya gerakan kaum radikalis-ekstrimis seperti Hizbut Tahrir, Al-Qaeda, Jamaah Islamiyah, dan berbagai kelompok Jihadis, baik di tingkat global maupun nasional dan lokal yang menimbulkan banyak persoalan dan kekerasan dalam perikehidupan umat manusia di era mutakhir. (Nashir, 2019)

Kebijakan negara dalam urusan hubungan luar negari menjadi hal yang penting. Oleh sebab itu, ketika persoalan terorisme dan gerakan yang "menentang arah demokrasi hadir" negara harus memberikan respon terutama dalam kebijakan luar negeri. (Sukma, 2004, 2003) Ini yang menyebabkan negara tidak boleh hadir berhadapan dengan gerakan-gerakan separatism dan terorisme yang mengganggu stabilitas politik secara keseluruhan. (Sukma, 2003) Indonesia berkepentingan menjadi negara yang mempromosikan moderatisme dan Islam sebagai agama mayoritas tidak bertentangan dengan demokrasi, sehingga tidak tampak Islam itu berwajah buruk. (Sukma, 2012). Bahkan secara promosi demokrasi adalah hal yang substansial dalam era pemerintahan Presiden Susilo Bambang Yudhoyono, khususnya pasca terjadinya bom Bali tahun 2002. (Weatherbee 2013). 
Sebagai negara majemuk, Indonesia tidak menjadi negara agama, tetapi juga tidak anti agama. Bahkan, dimensi agama menjadi perhatian negara dengan cukup meyakinkan. Berdirinya Ikatan Cendekiawan Muslim Indonesia (ICMI), Bank Muamalat, diperbolehkannya jilbab di sekolah negeri, kantor pemerintah, dan penyelenggaraan haji yang dikelola oleh kementerian agama merupakan bukti negara ini bukan anti agama. (Anwar, 1995, Effendy, 1998). Jika terjadi kesan adanya peminggiran terhadap umat Islam, hal ini sebenarnya lebih berhubungan dengan aktivitas politik praktis yang pada era Orde Demokrasi Terpimpin dan Orde Baru meminggirkan politisi seperti Mohammad Nasir, Kasman Singodimedjo, dan para aktivis politik lainnya. (Karim, 1999) Diskusi terkait demokrasi dan Islam mendapatkan perhatian para aktivis Islam. (Abdillah, 2000)

Namun demikian, masih ada kelompok kecil yang beranggapan bahwa Indonesia belum menjadi negara yang sesuai kehendak syariat Islam. (Nashir, 2006). Walaupun sebenarnya Indonesia dapat dikatakan sebagai negara dengan kebiasaan dan tradisi keislaman sehingga layak disebut sebagai negara dengan masyarakat Islam. Indonesia telah menegosiasikan nilai-nilai Islam dalam praktek pemerintahannya. Indonesia dapat menjadi contoh negara dengan penduduk muslim terbesar di dunia, namun tidak memaksakan Islam sebagai bentuk negara. (An-Naim, 2012)

Karenanya masalah radikalisme sebagaimana pada banyak masalah krusial di Indonesia mutakhir meniscayakan pemahaman yang mendalam dan menyeluruh agar tidak terjebak pada kedangkalan cara pandang dan langkah yang diambil dalam mengatasinya, karena suatu masalah pada umumnya tidaklah sederhana dan terlepas dari ruang sosiologis yang mengitarinya. Pemahaman terhadap radikalisme dan persoalan-persoalan keindonesiaan meniscayakan pendekatan dan pemikiran yang komprehensif dan mendalam, antara lain melalui berbagai pendekatan keilmuan. Dalam memahami radikalisme dalam konteks Indonesia dan keindonesiaan perlu pembacaan dan analisis yang multiperspektif serta sangat tidak memadai bila dicandra hanya dengan pandangan yang linier dan positivistik. 


\section{Memperkuat Moderasi Islam}

Gagasan Moderasi Islam dikesankan sebagai gagasan politik identitas Islam di Indonesia. Sebab ada kesan pasca Bom Bali 2002 Islam Indonesia menjadi sorotan keras dunia luar. Apalagi pasca Bom Pentagon Amerika. Demikian hal yang menjadi konsentrasi Islam Moderat kenapa harus dilakukan:

"Therefore, from this point of view, the use of Moderate Islam can be seen as the re-emergence of identity (in particular, Islamic identity) in Indonesia's foreign policy. More especially, it is arguably important to consider that the notion of Moderate Islam is, in fact, a political interpretation that tries to put Islam in a liberal democracy discourse (Hashemi 2009) insertion of Islam into liberal democratic discourse then differentiated "Good Muslim" -those who in the liberal democratic discourse- and "Bad Muslim" -those who were against liberal democracy and hence categorized as the enemy by the US government -in order to distinguish between "radical"” and "ordinary" Muslims (Mamdani 2002).

Sekalipun Islam Moderat atau moderatisme Islam terkait dengan persoalan demokrasi liberal dan kebijakan politik luar negeri, tetap saja bahwa gagasan tentang Islam itu harus terus dikembangkan ke ruang publik sehingga pengembangan Islam sebagai identitas umat Islam Indonesia tetap tumbuh dan berkembang tidak sebagaimana terjadi pada rezim Orde Demokrasi Terpimpin dan Orde Baru. (Kiersey 2009; Larner and Walters 2004; Wight 2009).

Terdapat banyak perspektif tentang Islam Moderat seperti dapat kita perhatikan dari beberapa pendapat ahli. Jillian Schwedler, (2006) memberikan pemahaman bahwa, moderasi itu merupakan proses sebuah perubahan yang selalu terjadi dari radikal menuju liberal. Moderasi akan tampak pada individu-individu yang demokratis, toleran, pluralis dan koopertif dalam bernegara. (Islam, T., \& Khatun, A. (2015).

Selain itu, moderasi akan terkait dengan persoalan institusi politik dan ekonomi yang mengubah dari dominasi negara menjadi dominasi masyarakat sipil, terutama dalam hal kekuasan ekonomi-politik. Kekuatan suara dominan menjadi karakteristik dalam menumbuhkan kekuatan moderatisme, termasuk dalam bidang ekonomi. Moderatisme seringkali disuarakan oleh kaum intelegensia-intelektual, bukan suara kaum awam. (Somer, M. (2014). 
Dalam bahasa Arab, moderasi itu diterjemahkan sebagai "washatiyah", yang di dalamnya memiliki unsur keadilan, atau keseimbangan, kebajikan, dan tengahan.(Al-Sallabi, 1999).

Dari berbagai pemahaman yang dikemukakan para akademisi dan peneliti tentang Islam dan Moderatisme kita dapat membaca secara kritikal bahwa persoalan moderasi merupakan konsep yang masih sangat "longgar untuk didiskusikan”. Oleh sebab itu, tampaknya moderasi perlu benar-benar mendapatkan perhatian dari kalangan akademisi dan aktivis sosial keagamaan, termasuk Muhammadiyah. Kita akan perhatikan gagasan moderasi sebagaimana di bawah ini sebagai bahan pertimbangan ketika membahas fenomena dan isu moderasi di Indonesia dan dunia.

Tabel 1.Argumen Moderasi dalam Literatur

\begin{tabular}{|c|c|c|c|}
\hline & Independent variable & Type of moderation & $\begin{array}{l}\text { Definition of } \\
\text { moderation }\end{array}$ \\
\hline $\begin{array}{l}\text { Schwedler } \\
\text { (2006) }\end{array}$ & Inclusion & $\begin{array}{c}\text { Participate in } \\
\text { democratic processes }\end{array}$ & $\begin{array}{l}\text { 'Movement from a } \\
\text { relatively closed and } \\
\text { rigid worldview to } \\
\text { one more open and } \\
\text { tolerant of alternative } \\
\text { perspectives'a }\end{array}$ \\
\hline $\begin{array}{l}\text { Wickham } \\
\text { (2004) }\end{array}$ & $\begin{array}{l}\text { Inclusion and social } \\
\text { learning }\end{array}$ & $\begin{array}{l}\text { Ideological } \\
\text { moderation }\end{array}$ & $\begin{array}{l}\text { Ideological } \\
\text { moderation and } \\
\text { respect for the } \\
\text { democratic processes }\end{array}$ \\
\hline Brooks (2002) & $\begin{array}{c}\text { Inclusion and political } \\
\text { liberalization }\end{array}$ & $\begin{array}{c}\text { Participation in } \\
\text { democratic processes }\end{array}$ & \\
\hline $\begin{array}{l}\text { El-Ghobashy } \\
\text { (2005) }\end{array}$ & Participation & $\begin{array}{c}\text { Ideological } \\
\text { transformation }\end{array}$ & $\begin{array}{c}\text { Ideological } \\
\text { moderation } \\
\text { and democratic } \\
\text { understanding } \\
\end{array}$ \\
\hline Clark (2006) & $\begin{array}{l}\text { (1) Spirit of compromise, } \\
\text { (2) more than a mere } \\
\text { tactical compromise, and } \\
\text { (3) intra organizational } \\
\text { discussion of compromise } \\
\text { Cross-ideological } \\
\text { cooperation }\end{array}$ & $\begin{array}{l}\text { Cross-ideological } \\
\text { cooperation }\end{array}$ & \\
\hline $\begin{array}{l}\text { Robinson } \\
\quad(1997)\end{array}$ & Organizational selfinterest & $\begin{array}{l}\text { Endorsing } \\
\text { democracy }\end{array}$ & Democracy \\
\hline
\end{tabular}




\begin{tabular}{|c|c|c|c|}
\hline $\begin{array}{c}\text { Wegner and } \\
\text { Pellicer (2009) }\end{array}$ & Party autonomy & $\begin{array}{c}\text { (1) Level of } \\
\text { disagreement } \\
\text { between party } \\
\text { and Islamic social } \\
\text { movement, and (2) } \\
\text { level of cooperation } \\
\text { with other (left) } \\
\text { parties }\end{array}$ & $\begin{array}{l}\text { 'Increasing flexibility } \\
\text { towards core } \\
\text { ideological beliefs }\end{array}$ \\
\hline Somer $(2007$ & State repression & $\begin{array}{l}\text { Ideological } \\
\text { moderation }\end{array}$ & \\
\hline Nasr (2009) & Economy/capitalism & Moderation & $\begin{array}{c}\text { Moving away from } \\
\text { extremism }\end{array}$ \\
\hline $\begin{array}{c}\text { Zakaria } \\
(2004)\end{array}$ & Economic liberalization & $\begin{array}{l}\text { Ideological } \\
\text { moderation }\end{array}$ & \\
\hline $\begin{array}{c}\text { Haedar } \\
\text { Nashir (2019) }\end{array}$ & inclusivism & $\begin{array}{l}\text { Wasathiyah- } \\
\text { moderation with } \\
\text { social changes }\end{array}$ & $\begin{array}{l}\text { Between extremism } \\
\text { and liberalism }\end{array}$ \\
\hline $\begin{array}{l}\text { Zuly Qodir } \\
\text { (2016) }\end{array}$ & Progressive & $\begin{array}{l}\text { Democratic accepted } \\
\text { in political system }\end{array}$ & $\begin{array}{l}\text { Responses for } \\
\text { humanity }\end{array}$ \\
\hline
\end{tabular}

\section{Memperkuat Keindonesiaan}

Saat Indonesia belum merdeka, pertempuran merupakan suatu yang niscaya dilakukan. Pasca Indonesia merdeka, Indonesia masuk dalam tahap mencari bentuk, nation building, dan becoming Indonesia. Kondisi semacam ini mengindikasikan jika dalam membentuk Indonesia terdapat banyak masalah baik dari dalam maupun dari luar. Halangan dari penjajah yang ingin menjajah kembali dan menguasai. Dari dalam kelompok-kelompok yang dikecewakan melakukan perlawanan dan pemberontakan. Nama Sekarmaji Mardijan Kartosuwirjo, Abdul Kahar Muzakkar dan Tengku Daud Breureueh adalah tiga serangkai yang dalam dokumen Indonesia sering disebutkan sebagai "pemberontak" dengan mengusung gagasan Islamic State di Indonesia. (Mc.Vey, 1987, Formichi, 2012: 203)

Pada saat negara berkembang mengarah pada personalisasi dan privatisasi, sebenarnya masalah keagamaan, kewargaan dan posisi semua warga negara kadang kurang mendapatkan perhatian. Terdapat tekanan di sana dan peminggiran. Kasus migran muslim di Eropa merupakan hal yang mendapatkan perlakuan kurang baik oleh sebagian penduduk non migran sehingga mendapatkan perhatian oleh para penegak HAM internasional. Hal seperti ini seperti dikatakan Edmunds, terkait Human Right and Migrant People: 
"People and human-rights practicalities. Europe's Muslim communities are encountering disproportionate impact from the issues raised by and political effects of these concerns. Security in its broad sense is essential to the exercise of human rights and a basic intended outcome of public policy. It denotes individuals' freedom from - and freedom from fear of - violation of their person and property, excessive compulsion by other individuals, organizations or governments and punishment or other negative consequences from taking actions that are legal and which others are allowed to take. As well as allowing its individual members to feel secure, a functioning society must enjoy collective security (the freedom of a country and its allies from invasion, terrorism, war, threats of war and intimidation) in order to create, strengthen and sustain individual rights. (Edmunds, 2017: 77)

Terdapat persoalan serius tentang keindonesiaan pada saat ini. Persoalan pengakuan warga negara minoritas secara etnis, agama, dan jenis kelamin kadang memberikan penghalang atas berkembangnya demokrasi di Indonesia yang berkualitas. Demokrasi Pancasila merupakan demokrasi yang telah lahir dari kebebasan sipil dari penjajahan, tekanan politik rezim otoriter, namun menghargai kelompok minoritas secara agama dan etnis tampak belum maksimal. Hal ini yang oleh Jeremy Menchick sebut sebagai "tolerance without liberalism", sebab terdapat perkembangan dan pertumbuhan demokrasi namun dalam makna demokrasi liberal elektoral, belum substansial demokrasi. (Menchik, 2016)

Pada level masyarakat bawah, perkembangan demokrasi dapat dikatakan membanggakan. Namun, pada level politisi dan elit kekuasaan, seringkali pertumbuhan dan perkembangan demokrasi terjadi pembajakan disebabkan adanya tarik menarik kepentingan antar elit tersebut. Hal semacam ini, menjadi salah satu penghalang mundurnya kualitas demokrasi yang diharapkan terus bergerak di Indonesia. (Menchik, 2019). Bahkan, dalam perkembangan terakhir, beberapa kasus Pemilihan Kepala Daerah terjadi jual beli suara yang menjadikan demokrasi berbiaya mahal karena terjadi "jual beli suara”. (Aspinal, 2019)

Moderasi Islam Indonesia berada dalam tantangan konservatisme yang sedang bergerak mendapatkan panggung politik. Hal ini menjadi tantangan serius organisasi Moderat seperti Muhammadiyah di Indonesia. Oleh sebab itu, “conservative turn" tidak dapat dianggap sebagai hal yang biasa saja sebab akan menghalangi pertumbuhan demokrasi yang berkualitas pasca reformasi 
berlangsung. Konservatisme merupakan persoalan serius Muhammadiyah. (Bastian and Nubowo, 2019)

Kondisi semacam itu menjadi tantangan keindonesiaan kita yang masih dalam tahap "membentuk" dan berkembang menjadi lebih dewasa secara politik. Kita tidak bisa membiarkan proses demokrasi Indonesia berada pada tangan para politisi yang tidak memiliki visi politik ke depan untuk kemajuan bangsa secara bermartabat. Karenanya dapat dipahami adanya kontroversi tentang konsep radikalisme yang menjadi wacana publik di Indonsia terakhir karena masih membawa muatan pandangan dan pelekatan yang ambigu, dengan kecenderungam mengaitkan radikalisme pada sebatas radikalisme agama atau lebih khusus lagi radikalisme Islam. Hal ini memberikan dampak yang negatif pada umat Islam.

Kontroversi itu tentu bukan pada persoalan setuju dan tidak setuju dalam menghadapi radikalisme tetapi lebih pada perdebatan tentang konsep, pemikiran, sasaran atau objek, cakupan, strategi atau cara, serta kebijakan tentang radikalisme di Indonesia. Tetapi lebih pada bagaimana masalah radikalisme dikaji dan dikonstruksi secara menyeluruh dengan sudut pandang yang mendalam dan multi perspektif, yang dapat didialogkan dalam kehidupan kebangsaan yang menjujung tinggi tradisi musyawarah sebagaimana spirit sila keempat Pancasila. Pancasila sebagai dasar negara harus kita jaga dan rawat itu pasti. Pancasila dengan rumusan yang ada tidak ada pertentangan sama sekali dengan Islam.

\section{Peran Penting Muhammadiyah}

Sebagai organisasi sosial keagamaan, Muhammadiyah sejak berdiri diniatkan bukan sebagai organisasi politik (partai politik), tetapi sebagai organisasi dakwah Islam amar ma'ruf nahi munkar. Nakamura (2012), menyebutkan Muhammadyah sebagai organisasi penyantun umat. Nakamura Said, "Established on November 18, 1912, Muhammadiyah has survived because of its solidarity, extensive networks, and activities in the fields of education, health, and poverty alleviation. Nonetheless, its political involvement is reflected more in national politics than in political parties". Muhammadiyah menjadi organisasi Islam yang memberikan kontribusi terhadap pencerdasan anak-anak bangsa, menjadikan bangsa ini beradab karena pendidikan dan menjadikan bangsa ini sehat jasmani karena mendapatkan perhatian dalam kesehatan fisik. 
Semangat ini merupakan bagian dari dakwah Muhammadiyah dalam mengembangkan Islam rahmatan lil alamin, sebagai bentuk konkret dari Islam Moderat dengan semangat pembaruan sebagaimana dilakukan pendiri Muhammadiyah, KH. Ahmad Dahlan. Sekalipun demikian, Muhammadiyah tidak alergi dengan gerakan politik, sebagai politik kebangsaan. Politik kebangsaan merupakan tabiat Muhammadiyah sebagai bentuk politik yang adi luhung, politik berpihak pada moralitas dan etika, bukan politik praksis yang sering tidak berlandaskan moral politik. (Nurmandi, 2015)

Gagasan politik yang berpijak pada moral-etika, sekalipun Muhammadiyah pernah terlibat dalam politik di Masyumi, seperti dikemukakan Alfian (1989),

"Mentions that Muhammadiyah is a non-political movement and as such it must be distinguished from organizations that make politics their profession. It tries not to involve itself in politics directly and openly. Previously, Muhammadiyah had been involved in such political movements as Syarikat Islam and Parmusi, with its political role being determined by a sort of situational logic. In the 1955 General Election, Muhammadiyah was part of the Masjumi Party."

Muhammadiyah tidak mengubah bentuk menjadi organisasi politik atau pun organisasi oposan dengan pemerintah. Namun, tidak berarti Muhammadiyah akan "tunduk dan tidak kritis" pada pemerintah. Muhammadiyah hendak memerankan posisinya sebagai mitra pemerintah sesuai dengan mandatnya dan fungsi check and balanced sehingga negara ini terus menjadi pengemban amanah rakyat. Muhammadiyah berusaha menjadi penengah atas semua gerakan Fkeagamaan (Keislaman) di Indonesia. Posisi seperti ini jelas tidak mudah dilakukan Muhammadiyah dengan pelbagai macam karakteristik pengikutnya. Muhammadiyah berusaha berada di tengah tidak memihak kepada ekstremisme dan partai politik yang cenderung bergerak ke arah mana yang lebih menguntungkan. (Nashir, 2006)

Muhammadiyah menempatkan dirinya sebagai gerakan sosial keagamaan yang bersifat melayani umat (masyarakat), sekalipun terdapat tarik menarik dengan kekuatan politik dari gerakan Islam Politik seperti Hizbut Tahrir Indonesia, dan partai politik. Namun, sebagai gerakan sosial keagamaan Muhammadiyah tetap berdiri di atas pendiriannya sendiri, tidak bergerak ke arah politik praktis. (Burhani, 2019). Muhammadiyah berada dalam "rangkaian moderatisme dan islamisme" yang menjadi kecenderungan pada sepuluh tahun terakhir di Indonesia. (Arifianto, 2019). Muhammadiyah berada dalam kondisi 
antara mengemban misi moderat dan misi keagamaan yang militan. Namun militan bukan dalam makna "melawan negara", tetapi militan bergerak untuk perubahan. (Burhani, 2019)

Berhadapan dengan pelbagai persoalan radikalisme dan terorisme, Muhammadiyah tetap kritis terhadap pendekatan yang dilakukan pemerintah yang mempergunakan cara-cara kekerasan. Namun demikian, tidak juga membenarkan perilaku terorisme yang merupakan "pelanggaran kemanusiaan”. Dalam kaitan ini, pendekatan non kekerasan tetapi pendekatan humanis menjadi hal yang perlu mendapatkan perhatian pemerintah. Istilah deradikalisasi sendiri menjadi persoalan yang krusial ketika berhadapan dengan masalah radikalisme dan terorisme. (Shcmid, 2013)

Kehadiran Muhammadiyah, dengan menegaskan bahwa negara Pancasila sebagai Darul Ahdi wa Syahadah, telah terang di hadapan kita semua bahwa Muhammadiyah tidak akan mengubah dasar negara atau pun bentuk negara yang telah menjadi kesepakatan banyak elemen bangsa. Amandemen UUD 1945, yang telah dilakukan sebenarnya dalam beberapa perspektif telah secara perlahan-lahan mengebiri keindonesiaan kita. Namun demikian, karena hal itu tuntutan bersama atas nama demokrasi, maka amandemen dilakukan kecuali mengamandemen Pembukaan yang di dalamnya termaktub Pancasila sebagai dasar negara. Amandemen berlaku untuk pasal-pasal dari UUD 1945 bukan pada Pembukaan 1945. Di sini Muhammadiyah berkeyakinan bahwa Indonesia telah sesuai dengan kondisi sosial budaya dan historis bangsa ini ketika awal mula diproklamirkan.

Muhammadiyah bertekad terus mengabdi untuk bangsa ini. Sekalipun kita ketahui dalam tubuh Muhammadiyah juga tidak satu garis pemikiran. Jika mengikuti Munir Mulkhan, Muhammadiyah ini pengikutnya beragam, ada yang cenderung seperti KH. Ahmad Dahlan, sehingga menjadi Dahlaniansebenarnya lebih akomodatif dengan tradisi dan kebudayaan namun dipahami berbeda. Seakan-akan Ahmad Dahlan anti tradisi dan kebudayaan. Padahal yang tidak dikehendaki oleh KH. Ahmad Dahlan adalah menjadikan tradisi sebagai syariah dan ibadah sunnah, apalagi ibadah mahdah. Ada pula Muhammadiyah yang sangat puritan-ini para pengikut Muhammadiyah yang lebih deket dengan salafi wahabi-dengan jargon utamanya ar ruju ila al-Qur'an wa as-Sunnah. Apapun yang tidak ada rujukan dan contoh dari Nabi dianggap sebagai hal yang dilarang dikerjakan inilah hal yang dikenal dengan sebutan bid'ah dalam Muhammadiyah. Dia sangat ingin sesuai dengan pedoman utama 
umat Islam yakni al-Qur'an dan Sunnah. Tidak bermasalah sebenarnya jika terkait dengan hal yang dikenal dengan ibadah mahdhah.

Selain itu ada pula pengikut Muhammadiyah yang mengawinkan tradisi dan syariah. Semacam memadukan kebiasaan dalam hidup dengan syariah yang dipahami. Asalkan tidak bertentangan dengan akidah maka orang Muhammadiyah tetap mengerjakan tradisi dan kebiasaan sekalipun oleh sebagian warga Muhammadiyah dianggap tidak sesuai Muhammadiyah yang asli-Muhammadiyah al ikhlas-puritan. Inilah yang oleh Geerzt dianggap sebagai keagamaan kaum abangan di masyarakat pedesaan Jawa. Selain itu juga ada warga Muhammadiyah yang mengawinkan kebiasaan dalam NU dengan Muhammadiyah. Terutama dalam hal muamalah dan siyasah politik duniawiyah. Muhammadiyah model ini merupakan perkawinan antara NU dan Muhammadiyah yang menjadi kultur beyond Muhammadiyah-biasanya di kalangan akademisi dan kaum muda progresif-transformatif bukan para pendakwah-mubaligh. (Mulkhan, 1999)

\section{Memutus Radikalisme}

Apapun namanya, radikalisme yang mengarah pada ekstremisme merupakan tindakan yang tidak sesuai dengan ajaran agama (Islam). Islam tidak mengajarkan seseorang untuk menjadi ekstrem dalam beragama. Islam mengajarkan agar orang beragama tidak berlebihan, tetapi bersifat tengahan (washatiyah) alias moderat. Tidak cenderung ke eksterm kanan liberal atau ke ekstrem kiri fasisme komunisme. Islam itu berada di tengah antara liberal dan fasisme sehingga menjadi rahmat seluruh umat manusia bahkan alam seisinya. Inilah yang menjadi titik tolak perlunya membangun moderatisme dalam beragama. Moderatisme tidak berarti tidak punya sikap. Moderat artinya bersifat tidak mendorong ke arah ekstremisme yang berlebihan.

Bahwa persoalan radikalisme, merupakan kosa kata yang tidak imun dari persoalan politik telah banyak diketahui para peneliti dan penulis. Radikalisme itu identik dengan salah satu kelompok tertentu yang membuatnya terpojok, dan ini tidak dapat dibenarkan. Radikalisme sebagai kosa kata sebenarnya netral saja. Dia merupakan turunan kata dalam tradisi filsafat yakni radix yang bermakna sampai ke akar-akarnya atau fundamental. Tetapi kata radikal menjadi pejoratif karena terdapat gagasan dan aktivitas yang dilakukan di belakangnya. Radikal dalam makna yang negatif bahkan politik sehingga radikal itu seperti 
aktivitas yang bertentangan dengan kemanusiaan dan keagamaan. Inilah makna kata radikalisme yang dimaksudkan dalam tulisan ini.

Hal-hal terkait dengan radikalisasi kita dapat memperhatikan demikian variatif apa yang dikatakan sebagai radikalisme dan proses radikalisasi: Ashour (2009):

"Radicalisation is a process of relative change in which a group undergoes ideological and/or behavioural transformations that lead to the rejection of democratic principles (including the peaceful alternation of power and the legitimacy of ideological and political pluralism) and possibly to the utilisation of violence, or to an increase in the levels of violence, to achieve political goals'; • Olesen (2009): 'the process through which individuals and organisations adopt violent strategies - or threaten to do so - in order to achieve political goals'; • Githens-Mazer (2009): 'a collectively defined, individually felt moral obligation to participate in 'direct action' (legal or illegal - as opposed to 'apathy')'; - Horgan \& Bradock (2010): 'the social and psychological process of incrementally experienced commitment to extremist political or religious ideology'; - Kortweg, et al. (2010): 'the quest to drastically alter society, possibly through the use of unorthodox means, which can result in a threat to the democratic structures and institutions'; - Mandel (2012): 'an increase in and/or reinforcing of extremism in the thinking, sentiments, and/or behaviour of individuals and/or groups of individuals". (Schmid, 2013: 17).

Terkait pula dengan ekstremisme yang menjadi bagian tak terpisahkan dalam gerakan keagamaan, termasuk di Indoesia, Muhammadiyah tidak mendukung gerakan ekstrem karena tidak sesuai dengan prinsip-prinsip teologi dan pedoman hidup Muhammadiyah. Muhammadiyah tidak akan memberikan ruang bagi gerakan ekstremisme karena bertentangan dengan paham moderasi Muhammadiyah. Ekstremisme seperti ISIS sebenarnya tidak sesuai dengan etika Islam, namun sering dipahami secara salah bahwa hal itu menjadi bagian dari ajaran Islam. (Joseph Chingyong Liow and Aida Arsoaile, 2019)

Oleh sebab itu, kita tidak dapat serta merta menyatakan bahwa mereka yang beragama Islam, Kristen, berjenggot, berjilbab, bersalib dan bersorban adalah kaum radikal. Identifikasi semacam ini akan memperkeruh hubungan sosial yang telah dibangun oleh organisasi Islam seperti Muhammadiyah di 
Indonesia dengan pemerintah. Hal yang perlu diketahui terkait radikalisme adalah perilaku yang mendukung dan cenderung mempergunakan kekerasan dalam bertindak dan menginginkan perubahan dalam sebuah negara dengan cara-cara kekerasan dan pemaksaan. Hak asasi manusia merupakan hal yang asasi dan harus dihormati oleh siapun yang, baik sedang berkuasa, tidak berkuasa ataukah telah selesai dalam berkuasa, memimpin negara. Hak asasi manusia harus dihormati oleh masyarakat sipil, tentara, polisi, aparat penegak hukum, ataupun pejabat negara dan pegawai biasa.

Persoalan radikalisme yang bersifat negatif tentu tidak dapat kita biarkan hidup di Tanah Air yang telah direbut dan menjadi milik semua elemen bangsa. Tidak boleh ada sekelompok orang mengklaim hanya dialah yang paling nasionalis, paling Indonesia dan paling berjasa dalam menjaga keindonesiaan. Sekalipun tanpa slogan Kami Indonesia, Kami Pancasila, NKRI harga mati dan seterusnya. Sejatinya Muhammadiyah dan elemenelemen bangsa lainnya telah benar-benar berjasa dalam merumuskan dan menjaga Indonesia. Muhammadiyah seperti kita ketahui sebenarnya telah berkhidmat untuk Indonesia dengan pelbagai aktivitas yang telah dilakukan selama 107 tahun. Muhammadiyah bersama elemen bangsa yang lain menjaga Indonesia dari gempuran kebodohan, kemiskinan, ketidak-makmuran dan penyakit dengan membuat amal usaha yang bermanfaat untuk masyarakat.

Oleh sebab itu juga, sebenarnya kita sebagai orang Muhammadiyah, pun tidak perlu berkecil hati jika ada pihak-pihak yang menganggap apa yang dilakukan Muhammadiyah tidak banyak membantu masyarakat. Bahkan, ada organisasi Islam yang menganggap bahwa Muhammadiyah tidak fokus dalam menjalankan aktivitasnya, hal ini tidak akan membuyarkan apa yang dilakukan Muhammadiyah. Muhammadiyah tetap bermanfaat di mata umat manusia dan Indonesia selama terus bekerja demi kesejahteraan dan kemanusiaan universal. Kadang terdapat rasa tidak terima dengan adanya ungkapan yang menyudutkan Muhammadiyah di ruang publik. Namun sejatinya itulah yang menjadi pelecut aktivitas dan aktivis Muhammadiyah dalam bermuhammadiyah. Apakah dia akan terus bersama Muhammadiyah ataukah hanya mengaku menjadi Muhammadiyah tetapi hanya akan marah jika ada orang lain mengkritik Muhammadiyah. Bermuhammadiyah itu tentu akan banyak kritik dan dukungan karena inilah kunci berorganisasi. 


\section{Penutup}

Dengan uraian seperti di atas, hal yang hendak kita sampaikan adalah persoalan moderasi sekalipun masih mengandung pelbagai pemahanan dari kalangan ahli, sebetulnya sikap moderat itu sesuai dengan gagasan Muhammadiyah, sebagai organisasi dakwah Islam, amar ma'ruf nahi munkar yang mengemban amanah perubahan (pembaruan). Pembaruan dari segala hal yang bersifat keburukan, kejahatan, keterbelakangan dan kebodohan. Muhammadiyah sebagai organisasi sosial keagamaan, terlahir sebagai "pembaharu" keadaan yang bersifat wasatiyah-tengahan, tidak ekstrem kanan atau ekstrem kiri. Tidak liberal tetapi juga tidak konservatif. Inilah sikap moderasi Muhammadiyah yang dapat dirunut dari pendiri Muhammadiyah, KH. Ahmad Dahlan.

Radikalisme, ekstremisme, dan deradikalisasi menjadi kosa kata yang paling popular pasca terjadinya Bom di Twin Tower Pentagon serta Bom Bali Pertama di dunia Internasional, regional dan nasional. Oleh sebab itu, tidak perlu gegabah dengan istilah radikalisme, ekstremisme, dan terrorisme. Fakta ada kekerasan atas nama agama terjadi di semua agama. Kita tidak dapat mengelak atas keadaan ini. Namun juga kita tidak dapat dengan mudah menuduh kelompok tertentu dengan idiom radikal, ekstremis, atau teroris, sebab semuanya terdapat penyebab yang saling berkelit belindan. Hal yang dapat kita lakukan adalah cermat memperhatikan gejala yang muncul, kemudian mengantisipasi dan merespon dengan cara-cara yang soft power, bukan over acting.

Muhammadiyah, sebagai organisasi sosial keagamaan, siap bekerjasama dengan pihak mana pun, tanpa menjadi "part of the part" kekuasaan atau pun menjadi bagian kekuasaan. Muhammadiyah akan tetap berkontribusi untuk mencerdaskan bangsa, menjadikan anak-anak bangsa ini bermartabat, mulia dan tidak terbelakang. Muhammadiyah akan tetap bersikap kritis pada pihak manapun yang menyengsarakan, meninggalkan dan mengkhianati rakyatnya. Sebab mencerdaskan rakyat, mensejahterakan dan memerdekakan adalah amanat Undang-Undang Dasar 1945 yang merupakan milik bersama. 


\section{Daftar Putaka}

Aspinal, Edward and Ward Berenschot, Democracy for Sale: Election, Clientalism and the State in Indonesia, Itacha Cornel University, USA, 2019

Ahmad Najib Burhani, Al-Tawassul wa-l I'tidal: The NU and Moderatism in Indonesian Islam Source: Asian Journal of Social Science, Vol. 40, No. 5/6 (2012), pp. 564-581 Published by: Brill Stable URL: https://www. jstor.org/stable/43498869 Accessed: 05-12-2019 03:27 UTC

Anwar, M. Syafii, Pemikiran dan Aksi Islam Indonesia: Cendekiawan Muslim pada Era Orde baru, Paramadina, Jakarta, 1995

Alex P. Schmid, Radicalisation, De-Radicalisation, Counter-Radicalisation: A Conceptual Discussion and Literature Review, ICCT Research Paper March 2013

Alexander Raymond Arifianto, "Rising Islamism and the Struggle for Islamic Authority in Indonesia” in TRaNS: Trans-Regional and-National Studies of Southeast Asia, 2019

Al-Sallabi, A M. (1999).Al-Wasatiyyah Fi Al-Quran Al-Karim. Amman: Jordan, Dar al-Nafais \& Dar alBayariq

Ashour, O. (2007). Lions tamed? An inquiry into the causes of de-radicalization of armed Islamist movements: The case of the Egyptian Islamic group. Middle East Journal, 61 (4), 596-625.

Ashour, O. (2008). De-radicalization of jihad?the impact of Egyptian Islamist Revisionists on Al-Qaeda. Perspectives on Terrorism, 2 (5).

Ashour, O., \& Boucek, C. (2009).De-Radicalisation in Egypt, Algeria, and Libya. Washington, DC: Carnegie Endowment for International Peace, 16 April.

Ashour, O. (2010). Online de-radicalization? Counter violent extremist narratives: Message, messenger and media strategy. Perspectives on Terrorism, 4 (6).

Ashour, O. (2008). Islamist de-radicalization in Algeria: Successes and failures (Policy Brief No. 21). The Middle East Institute, November.

Bastian, Leonardo, C and Andar Nubowo, "The Conservative Turn" in Indonesian Islam: Implication for the Precidential 2019 Elections, Asie, 
Vision, No 106, Ifri, March, 2019

Bayat, Asef. 2007. Making Islam Democratic: Social Movements and the PostIslamist Turn. Stanford, CA: Stanford University Press.

Burhani, Ahmad Najib, Between Social Services And Tolerance: Explaining

Religious Dynamics In Muhammadiyah, Trends in Southeast Asia, 2019 no. 11, 2019 ISEAS - Yusof Ishak Institute, , Singapore

Bruinessen, Martin van, ed. 2013. Contemporary Developments in Indonesian Islam: Explaining the "Conservative Turn." Singapore: Institute of Southeast Asian Studies.

Chinyong Liow, Joseph and Aida Arosoaie, The Sound of Silence: Nuancing Religiopolitical Legitimacy and Conceptualizing the Appeal of ISIS in Malaysia, Source: Contemporary Southeast Asia, Vol. 41, No. 1, Special Issue: MILITANT ISLAM IN SOUTHEAST ASIA: New Insights into Jihad in Indonesia, Malaysia and the Philippines (April 2019), pp. 86-113 Published by: ISEAS - Yusof Ishak Institute Stable URL: https://www. jstor.org/stable/10.2307/26664206

Effendy, Bahtiar. 1998. Islam dan Negara: Transformasi Pemikiran dan Praktik Politik Islam di Indonesia. Jakarta: Paramadina.

Formichi, Chiara, ISLAM AND THE MAKING OF THE NATION : Kartosuwiryo and political Islam in twentieth-century Indonesia, Published by: KITLV Press Koninklijk Instituut voor Taal-, Land- en Volkenkunde (Royal Netherlands Institute of Southeast Asian and Caribbean Studies) P.O. Box 95152300 RA Leiden The Netherlands

Haedar Nashir; Zuly Qodir; Achmad Nurmandi; Hasse Jubba; Mega Hidayati, MUHAMMADIYAH'S MODERATION STANCE IN THE 2019 GENERAL ELECTION Critical Views from Within, Al-JØmi'ah: Journal of Islamic Studies - ISSN: 0126-012X (p); 2356-0912 (e) Vol. 57, no. 1 (2019), pp.1-24, doi: 10.14421/ajis.2019.571.1-24

Hashemi, Nader. 2009. Islam, Secularism, and Liberal Democracy: Toward a Democratic Theory for Muslim Societies. New York, NY: Oxford University Press

Hefner, Robert W. 2000. Civil Islam: Muslims and Democratization in Indonesia. Princeton, NJ; Oxford: Princeton University Press.

Horgan, J. (2008). De-radicalisation or disengagement?A process in need of clarity and a counterterrorism initiative in need of evaluation.Perspectives on Terrorism, 2 (4). 
Horgan, J. (2009). Individual disengagement: A psychological analysis. In T. Bjørgo, \& J. Horgan (Eds.), Leaving terrorism behind: Individual and collective disengagement (pp. 17-30). Abingdon: Routledge.

Horgan, J., \& Braddock, K. (2010). Rehabilitating the terrorists? Challenges in assessing the effectiveness of deradicalization programs. Terrorism and Political Violence, 22 (2), 267-291.

Horgan, J., \& Taylor, M. (2010). Disengagement, de-radicalisation and the arc of terrorism: Future directions for research. In R. Coolsaet (Ed.), Jihadi terrorism and the radicalisation challenge: European and American experiences (pp. 173-187). Farnham: Ashgate.

Horgan, J., \& Braddock, K. (2011). Evaluating the effectiveness of deradicalisation programs: Towards a scientific approach to terrorism risk reduction. In S. Canna (Ed.), Countering violent extremism: Scientific methods \& strategies (pp. 158-164). Washington, DC: NSI.

Horgan, J. (2012). Discussion point: The end of radicalization? National Consortium for the Study of Terrorism and Responses to Terrorism (START); availableat:http://www.start.umd.edu/start/announcements/ announcement.asp?id=416

Islam, T., \& Khatun, A. (2015). "Islamic Moderation" in Perspectives: A Comparison Between Oriental And Occidental Scholarships. International Journal of Nusantara Islam, 3(2), 69-78.

Kiersey, Nicholas J, and Doug Stokes. 2011. Foucault and International Relations: New Critical Engagements. London: Routledge.

Korade, M. (2008).Saudis getting 'Intriguing Results' with de-radicalisation program. CQ Homeland Security 'in the News', 2 October; available at: http://www.gwumc.edu/hspi/old/news/cq100208.

Kruglanski, A.W., Gelfand, M., \& Gunaratna, G. (2010). Detainee deradicalisation: A challenge for psychological science. Observer (Assoc. for Psychological Science), 23 (1); available at http://www. psychologicalscience.org/observer/getArticle.cfm?id=2607.

Larner, Wendy, and William Walters. 2004. "Introduction: Global Governmentality: Governing International Spaces.” In Global Governmentality: Governing International Spaces, eds. Wendy Larner and William Walters. London: Routledge.

Mamdani, Mahmood. 2002. "Good Muslim, Bad Muslim: A Political Perspective on Culture and Terrorism.” American Anthropologist 104(3): 766-75. 
Menchik, Jeremy. 2016. Islam and Democracy in Indonesia: Tolerance without Liberalism. Cambridge: Cambridge University Press.

Mulkhan, Abdul Munir, Islam Murni di Pedesaan Jawa, Bentang Budaya, Yogyakarta, 1999

Nashir, Haedar, Islam Syariah: Reproduksi Idelogi salafsime di Indonesia, PSAP, 2006, diterbitkan kembali Mizan, 2013

Nurmandi, Achmad, Ijtihad Politik Muhammmadiyah: Politik sebagai Amal Usaha, JKSG-Pustaka Pelajar, 2015

Somer, M. (2014).Moderation of religious and secular politics, a country's "centre" and democratization. Democratization, 21(2), 244-267.

Suveyda Karakaya \& A. Kadir Yildirim (2013) Islamist moderation in perspective: comparative analysis of the moderation of Islamist and Western communist parties, Democratization, 20:7, 1322 1349, DOI: $10.1080 / 13510347.2012 .696612$

Schwedler, J. (2011). Faith in Moderation: Islamist Parties in Jordan and Yemen. Cambridge: Cambridge University Press.

Qodir, Zuly, Radikalisme Agama: Gerakan Keagamaan di Indonesia, Pustaka Pelajar, 2016

Rumadi. 2015. Islamic Post-Traditionalism in Indonesia. Singapore: ISEASYusof Ishak Institute.

Steger, Manfred B. 2008. The Rise of Global Imaginaries: Political Ideologies from the French Revolution to the Global War on Terror. Oxford: Oxford University Press.

2003. Islam in Indonesian Foreign Policy: Domestic Weakness Dilemma of Dual Identity. London: Routledge.

2004. "War on Terror, Islam and the Imperative of Democracy." Asia Europe Journal 2(1): 85-93.

Wight, Colin. 2006. Agent, Structures, and International Relations: Politics as Ontology. Cambridge: Cambridge University Press.

2009. “Theorising Terrorism: State, Structure, and History." International Relations 23(1): 99-106. 